\title{
Приложение на Coblator II system при тонзилектомия
}

\author{
Пл. Недев, Г. Илиев, Д. Марев, М. Милков \\ Медицински университет „Проф. П. Стоянов“ - Варна \\ Клиника по УНГ-болести при УМБАЛ „Св. Марина“ - Варна
}

\begin{abstract}
Резюме
Целта на проучване е да сравни интра- и постоперативни впечатления от нашия опит, едно клинично проучване и научната информация от други презентации при пациенти тонзилектомирани с Coblator system II (ArthroCare Corp) спрямо със студената дисекция. Бяха сравнени болката на първия следоперативен ден, употребата на аналгетици, вида диета, продължителността на болката, температурата, отсъствие от училище, интра- и постоперативно кървене. Основавайки се на нашия опит и метаанализа, ние можем да направим заключение, че тонзилектомията с коблатор е сигурен и ефективен метод, сравнен със студената дисекция.
\end{abstract}

\begin{abstract}
The aim of this study was to compare intra and post-operative recovery over our experience, one clinical research and Medline scientific information in patient submitted to tonsillectomy using a Coblator system II ( ArthroCare Corp) to cold dissection. Pain intensity on the first day, use of analgesics, type of diet, and days of pain, fever, nausea, and absence from school, intra- and postoperative blooding were determined.

Based on our findings from the meta-analysis and experience, we conclude that coblation is a safe and effective method for tonsillectomy compared to cold dissection.
\end{abstract}

Key words: Tonsillectomy, Cold dissection, Coblation

\section{Увод}

Оперативното премахване на тонзилите обикновено е безопасна процедура и е най-честата рутинна операция на оториналаринголозите, но въпреки това свързана с някои известни усложнения. Основните оперативни техники са въведени в края на 19-ти и началото на 20-ти век.

Един от съвременните начини за тонзилектомия е „коблатор - техниката“. При „коблатор-техниката“ накрайникът едновременно осъществява аблация (при минимална термична увреда на околната здрава тъкан), резекция, аспирация, коагулация и хемостаза. Методът работи на принципа на радиочестотната аблация, при която се разкъсват молекулярни връзки без да се използва топлина.

При използването на коблатор е препорьчително да се работи под микроскоп. Започва се от долния полюс на тонзилата като се очертава нагоре дисекционната линия. След това със защипващия инструмент тонзилата се придърпва медиално и ротира, движение наподобяващо отваряне на книга, до пълното и отстраняване. Всяко кървене, дори и минимално се коагулира своевременно.

\section{Методи на изследване}

За източник на информация сме ползвали:

- 10 публикации на различни автори, открити с ключови думи „Coblator tonsillectomy“, публикувани в специалзирани научни сайтове в периода $2004-2011$ г.; 

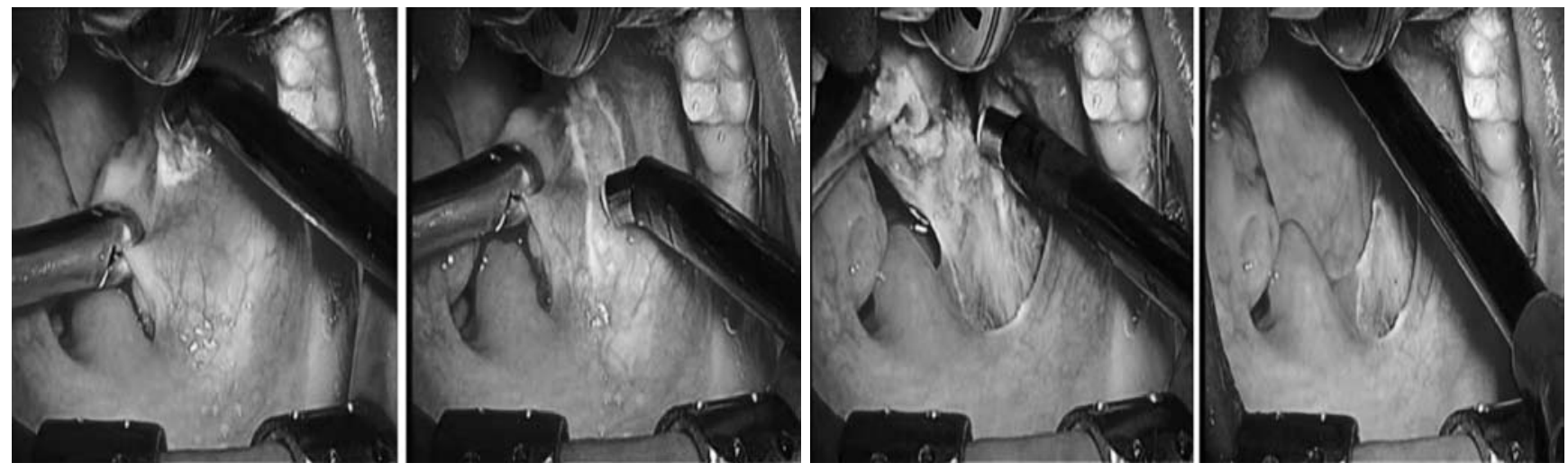

Фиг. 1, 2, 3, 4. Тонзилектомия с коблатор (изображението е от рекламните фрилми на Coblator II system)

- 1 проучване на ВМА - София, в което се сравняват „,конвенционалната“, „ултразвуковата техника“ с хармоничен скалпел и „коблатортехниката“" при тонзилектомия;

- Собствения опит с „коблатор-техниката“

\section{Цел}

Целта на нашата презентация е да се сравни коблатор техниката с други методи за тонизилектомия по отношение на времетраене на операцията, интра-, следоперативно кървене, болка и време на възстановяване.

\section{Резултати и дискусия}

Babademez M. А. сравнява при тонзилотомия следоперативната болка, връщането към нормална диета и активност при използването на коблатортехниката и други методи (лазер, радиочестотна аблация). При коблатор-техниката болката веднага следоперативно е най-ниска, пациетите се нуждаят най-малко от обезболяващи и се връщат най-бързо към нормална диета. Една година след извършване на оперативната намеса реоперация по повод хипертрофия на тонзилите не се е наложила само при коблатор-техниката. (1)

По отношение на постоперативна болка след тонзилектомия - най-безболезнена е техниката с коблатор, а най-болезнена - техниката с хармоничен скалпел, което се обяснява с по-голямата дълбочина на проникване на ултразвука и съответната увредата на околните тъкани. (2) Някои автори посочват разлика в следоперативната болка в подкрепа на коблатор техниката сравнена с други методики само в първите 10 дни (3), а според Polites - само в първите 4 дни. (4)
Glade сравнява постоперативната болка след тонзилектомия в продължение на четири години, 1997 случая на аденотонзилектомия при деца. Най-слаба болката е отново при коблатор техниката в сравнение с другите методики. (5) Средно 5 дни трябват за отшумяване на болката при тонзилектомия с коблатор срещу средно 10 дни при класическия метод („студена дисекция“"); около 6 дни са необходими до завръщане на училище при коблатор техниката и около 9 - при класическия метод; средно три дни е необходимо приемането на болкоуспокоителни при коблатор техниката и средно пет дни - при класическия метод; (6)

По-ранното отзвучаване на болката дава възможност за по-ранен прием на течности от пациентите и по-бързото им връщане към тяхната нормална ежедневна активност. $(1,2,3)$

По отношение на интраоперативно кървене - най-минимално е кървенето при техниката с коблатор, което осигурява комфорта на хирурга (оперативното поле е чисто) и спестява излишна крьвозагуба на пациента. (2) Сравнението на коблатор техниката с тази на електрокаутер техниката и „PlasmaKnife“ по отношение на интраоперативното и постоперативното кървене показва сходни резултати. $(5,7)$

По отношение на постоперативно кървене най-минимално е кървенето при техниката с коблатор, а следваща е техниката, използваща хармоничен скалпел. (2)

При наблюдаваните групи пациенти, не бяха намерени съществени различия по отношение късните хеморагии между оперираните с трите вида оперативни техники. Това най-вероятно се дължи на патофизиолочиния им механизъм, а 
именно - отпадане на постоперативния налеп и ерозия на подлежащ сьд. (2)

Използването на коблатор техниката повишава риска от следоперативно кървене и предполага предварително подбиране на подходящи случаи и подготвени специалисти. (8)

Мета-анализ на Ralph Mösges показва честота от $4.1 \%$ кръвоизливи като цяло (интра-, следоперативни, некласифицирани) и определя коблатор техниката като безопасна и ефективна. (9)

При коблатор техниката има повече от два пъти по-мальк риск за дехидратация след тонзилектомия в сравнение с електрокаутер техниката. (5) По отношение на времетраене на оперативната интервенция коблатор техниката отнема помалко време от класическия метод $(2,10)$, е повремеемка спрямо ултразвуковата техника (2), и има относително сходни резултати като времетраене с микродебридер техниката. (10)

\section{Литература}

1. Милков, М., И. Ценев, Д. Марев, Ц. Тончев. Критичен анализ на биполярна радиочестотна термотерапия, използвана за редукция на мекото небце и носните конхи при хабитуално хъркане. Международен бюлетин по оториноларингология. (Варна), 4, 2008, № 1, 46-53.

2. Недев, П., Г. Бояджиев, М. Милков. Видове интервенции при лечение на хъркане и обструктивна сънна апнея.- Международен бюлетин по оториноларингология. (Варна), 4, 2008, № 2, 47-51.

3. Babademez, M.A., Yurekli, M.F., Acar,B., Gunbey, E ; Acta OtoLaryngologica; volume 131, Issue 7, July 2011, Pages 750-756.

4. Георгиева Н., Златанов Хр .,Цветков В. - УНГ-клиника ВМА - София, „Тонзилектомия - съвременни оперативни техники” XII Белинов симпозиум и Национален конгрес по оториноларингология. Велико Търново 2011 м. ноември - устна презентация.

5. Parsons, S.P., Cordes, S.R., Comer, B.; Otolaryngology - Head and Neck Surgery; Volume 134, Issue 1, January 2006, Pages 106-113

6. Polites, N., Joniau, S., Wabnitz, D., Fassina, R., Smythe, C., Varley, P., Carney, A.S.; ANZ Journal of Surgery; Volume 76, Issue 4, April 2006, Pages 226-229
Опита с „коблатор-техниката“ в нашата клиника показва по-добри резултати относно интра- и постоперативното кървене, следоперативната болка и възстановяване спрямо класическия метод. Късни следоперативни хеморагии не са наблюдавани. В този смисъл техниката е подходяща и при пациенти с относителни противопоказания за аденотонзилектомия, като различни видове коагулопатии (11).

\section{Заключение}

Използването на коблатор при тонзилектомия е съвременна техника, лесна, бърза за изпълнение и значително по-безопасна от гледна точка на интра- и постоперативни хеморагии, с по-кратък въстановителен процес спрямо „студената дисекция“.

7. Glade, R.S., Pearson, S.E., Zalzal, G.H., Choi, S.S.; Otolaryngology - Head and Neck Surgery; Volume 134, Issue 5, May 2006, Pages 852-855

8. L. Di Rienzo Businco, G. Coen Tirelli; ACTA otorhinolaryngologica italica 2008; 28: 67-72

9. Lipan, M., Dinh, C., Younis, R.; Laryngoscope, Volume 119, Issue SUPPL.1, 2009, Page 144

10. Lancet, Volume 364, Issue 9435, 21 August 2004, Pages 697-702

11. Ralph Mo"sges, Martin Hellmich, Silke Allekotte, Kerstin Albrecht, Myriam Bo"hm; Eur Arch Otorhinolaryngol (2011) 268:807-816, DOI 10.1007/s00405-011-1535-9

12. Wilson, Y.L., Merer, D.M., Moscatello, A.L.; Laryngoscope, Volume 119, Issue 1, January 2009, Pages 162-170

13. Недев П, Калева В. Хемофилия В и аденотонзилектомия. Литературен обзор и представяне на случай. Международен бюлетин по оториноларингология 2008, бр. 1, 43-46 